\title{
Anal paracoccidioidomycosis. An unusual presentation of disseminated disease
}

\author{
Paracoccidioidomicose anal. Apresentação pouco comum de uma doença disseminada
René Aloisio da Costa Vieira ${ }^{13}$, Ademar Lopes ${ }^{2}$, Henrique Vilela Oliveira ${ }^{3}$, Otávio Monteiro Becker Júnior ${ }^{3}$, Danillo Stanzani Júnior ${ }^{3}$, Abaete Leite do Carmo ${ }^{4}$ and Moacir de Ribeiro de Castro Junior ${ }^{5}$

\begin{abstract}
We report a patient with an unusual anal ulceration. The biopsy of an anal lesion and subsequent studies revealed a disseminated form of paracoccidioidomycosis, observed in the lungs, small and large bowel. The anorectal disease frequently represents a secondary site of disease, and the patient must be better evaluated. Key-words: Paracoccidioidomycosis. Paracoccidioides brasiliensis. Anorectal disease. South American Blastomycosis.
\end{abstract}

Resumo Relatamos um paciente com uma lesão anal incomum. A biópsia da ulceração anal e estudos subsequentes, revelaram a forma disseminada da paracoccidioidomicose presente no pulmão, intestino delgado e grosso. A doença anorretal freqüentemente representa um sítio secundário da doença, devendo o paciente ser melhor avaliado.

Palavras-chaves: Paracoccidioidomicose. Paracoccidioides brasiliensis. Doença anorretal. Blastomicose sul Americana.

Paracoccidioidomycosis (PM) is a fungal infection caused by Paracoccidioides brasililiensis ${ }^{114}$. The main portal of entry is the lung. Hematogenous dissemination of the fungus may occur at this time, with the establishment of metastatic foci in any organ. The lungs are the main organs involved, present in 42 to $89.4 \%$ of the cases. Intestinal involvement ranges from 2.7 to $28.4 \%$; and anal lesions are present only in 1.3 to $2.4 \%$ of the patients ${ }^{1114}$. The pathogenesis of anal lesions remains unclear ${ }^{14}$. It may be secondary from a systemic disease or a local disease. We report a case of systemic $P M$, initially evaluated because of an anal ulceration.

\section{CASE REPORT}

A sixty-year-old male patient, from Minas Gerais, Brazil, with a history of perianal nodulation for two years, initially painless, which coursed into local abscess and spontaneous drainage, developing into a painful, plane ulcerated lesion, presenting purulent secretion. He did not present any change in bowel habits, neither abdominal colic, bleeding, pain nor abdominal tumor. Seven months previous to the evaluation, he started showing dysphonia, weight loss and, two months prior to the examination, he had sporadic coughing, progressive dyspnea with no expectoration.

Anal inspection revealed a plane ulcerated lesion with regular borders with granulation tissue and fibrinous exudate, damaging the anterior and right perianal skin, spreading the pectineal line (Figure 1). Digital examination revealed sphincteral hypotony and absence of peripheral adenopathy. Because of the unusual appearance of this lesion superficial biopsies were taken at the time of the initial examination. Biopsy showed $P$. brasiliensis in a granulomatous chronic inflammatory process.

Chest X-Ray showed pulmonary diffuse infiltrate (Figure 2A). The chest tomography (CT) showed bilateral interstitial reticulonodular infiltrate, with small cavities, mainly in the medium third and the base of both lungs (Figure 2B). The abdominal CT did not show any lesion. Endoscopy showed an epiglottic edema, with absence of esophageal, gastric or duodenal lesion. The small bowel transit time was markedly prolonged, and showed

1. Emergency and 2. Pelvic Surgery Departments of the A.C. Camargo Cancer Hospital, São Paulo, São Paulo State. 3. Surgery Service of Municipal Hospital Dr. José de Carvalho Florence. 4. Laboratory of Pathology of São José dos Campos. 5. Image Department of Pio XII Hospital, São José dos Campos, São Paulo State, Brazil.

Address to: Dr. René Aloisio da Costa Vieira. R. Pedro Tursi 240/84, 12230-090 São José dos Campos, SP, Brazil.

Tel: 5511 3971-7530; Fax: 5511 3941-7530;

e-mail: renecv@directnet.com.br

Recebido para publicação em 5/4/2001. 


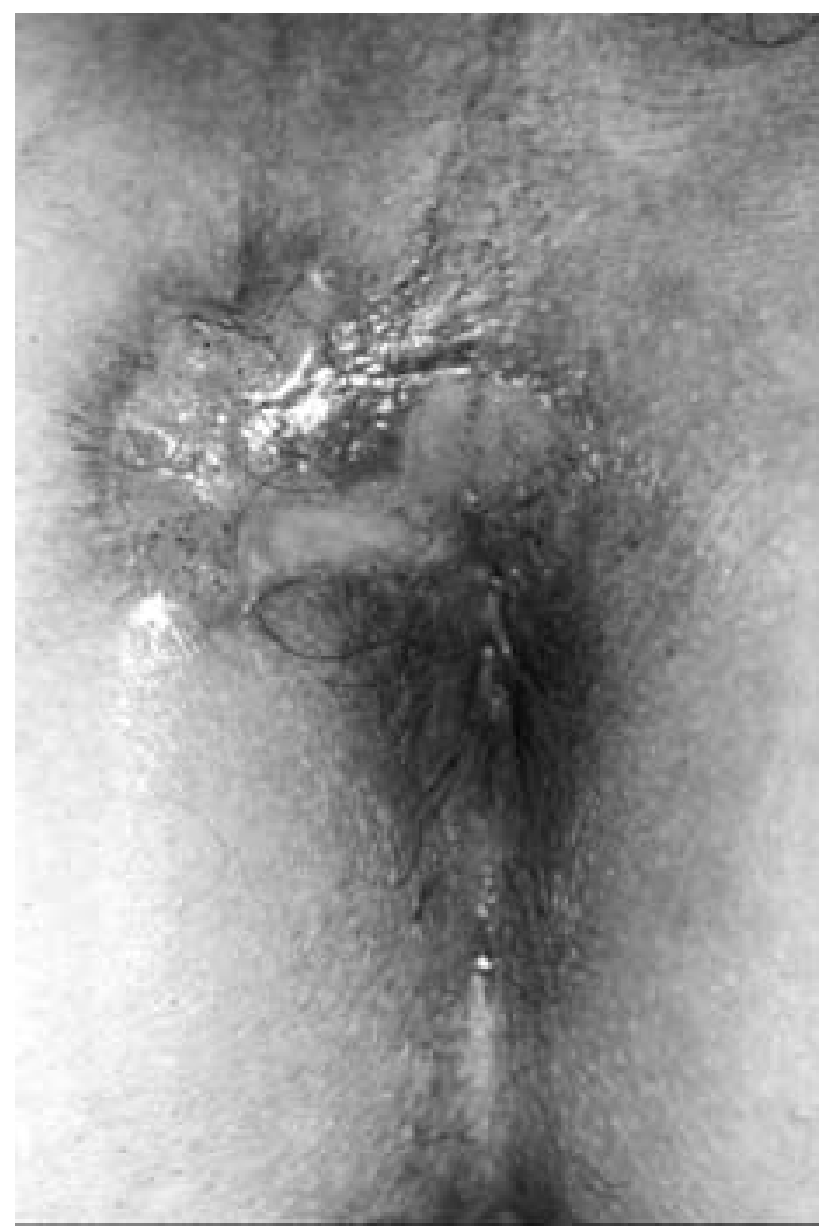

Figure 1 - Anal lesion caused by Plasmodium brasiliensis.

bowel irregularity in the jejunoileal region. Colonoscopy showed in transverse colon a $5 \mathrm{~mm}$ plane ulceration with erythema, surrounded by a white border (Figure 3A); and in the splenic flexure an edematized ring-shaped ulcerated lesion, with elevated borders, and precise limits, covered by fibrin

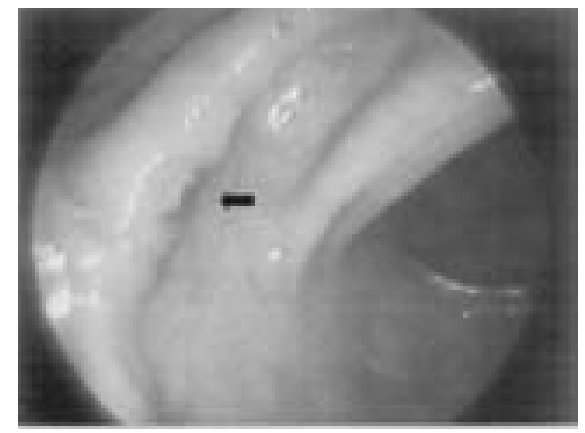

Figure $3 A$ - Colonoscopy. Upper:plane ulcerated lesion, in transverse colon.

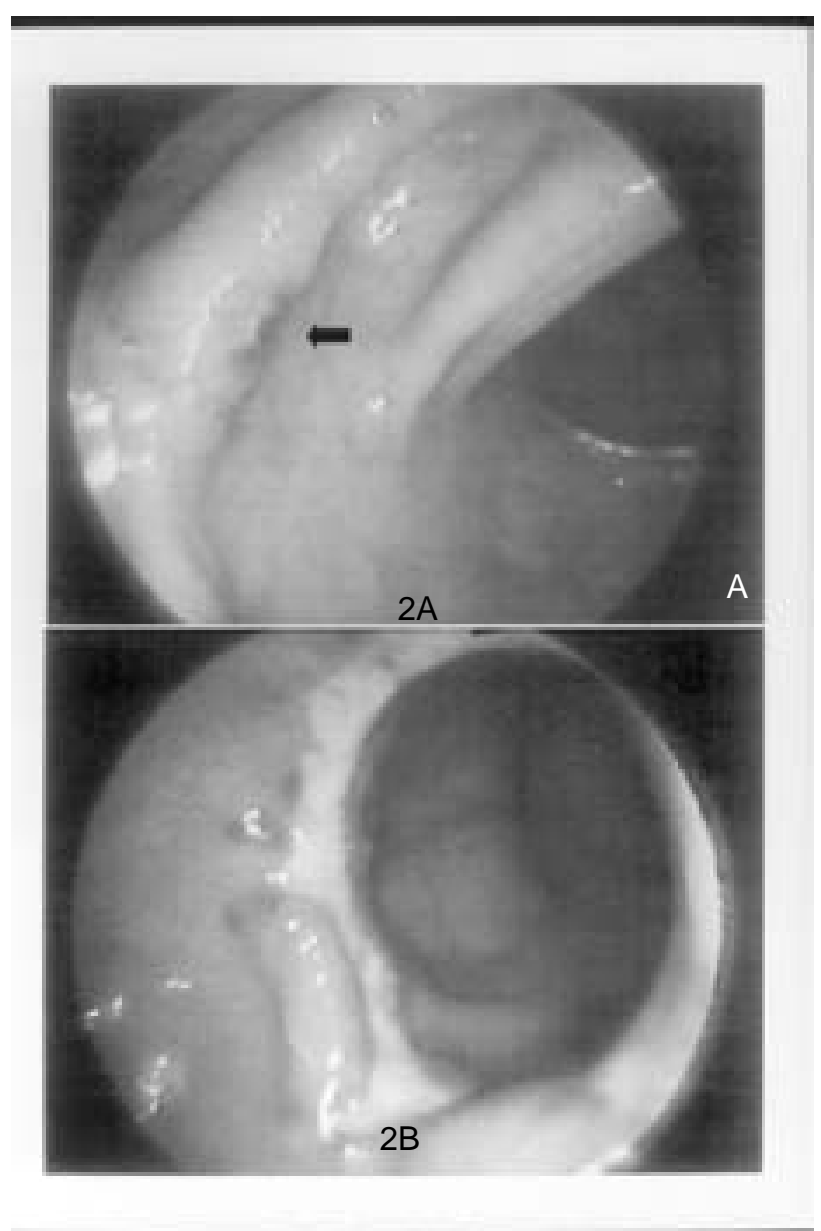

Figure $2 A$ - Pulmonary disease. Upper: conventional radiology. Figure $2 B$ - Pulmonary disease. Lower: thorax tomography.

(Figure 3B). The splenic angle biopsy showed colonic PM. Serology by immunodiffusion technique was positive in the titration $1 / 8$. The patient initiate treatment with sulfadiazine $2 \mathrm{~g} / \mathrm{d}$ for 12 months. In a month all signals and symptoms disappeared, with complete regression of anal lesion.

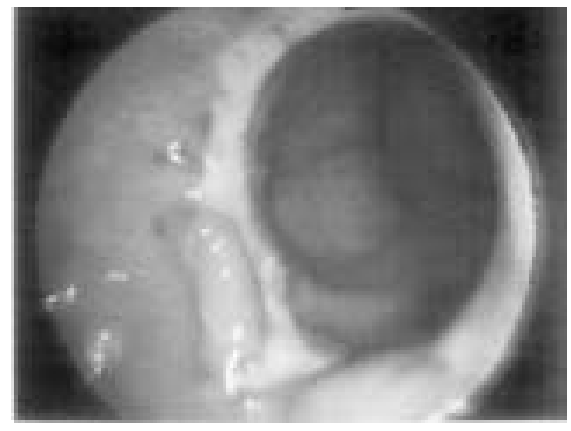

Figure 3B - Colonoscopy. Lower: granulomatous circumferential lesion in the descendent colon. 


\section{DISCUSSION}

Paracoccidioidomycosis is an endemic disease in Central and South America. Anal PM is a rare manifestation, with few reports in current literature, all of them in the Portuguese language ${ }^{416}$.

The pathogenesis of anal manifestations is unknown, there being controversies whether it is a secondary or primary lesion, because insufficient information in current literature ${ }^{13}$. The first hypothesis is based on the reports of the pulmonary disease in most of the patients with the anal form therefore, the anal manifestation would be a secondary form of the disease ${ }^{516}$. The second hypothesis is based on the report of anal hygiene with the use of wild leaves ${ }^{5}$, however, it seems hardly probable due to the lack of systemic research in previous reports ${ }^{4}$.

If we assume that infection by $P$. brasiliensis occurs through the respiratory route, it is from the lung and from the mediastinal lymph nodes that dissemination to the intestine occurs, through hematogenic or lymphatic routes ${ }^{14}$. Another route might be the intestinal tract, due to the presence of the disease in the small intestine and in the colon, in spite of the absence of lesions in the upper digestive tract $^{9}$. The anal disease can not justify a disseminated disease.

In the present case, the authors observed that in spite of the first symptom being directly related to the anorectal region, the main dissemination focus of the disease was pulmonary, justified by the patient's progressive dyspnea and radiological results. The absence of the oral and esophagus-gastric disease and the absence of abdominal adenomegaly suggest a systemic disease possibly with hematogenic dissemination, secondary to a pulmonary primary infection. In spite of above information we conclude that the anal ulceration is part of a disseminated disease and this case can be classified as a chronic multifocal form of Paracoccidioidomycosis ${ }^{8}$.

Anal PM lesion is characterized by an ulcerated lesion, with hardened plane or elevated borders, with a granulomatous background, painful, associated or not to purulent or sanguinolent secretion which affects frequently the anal hemi-circumference ${ }^{4} 16$. The differential diagnosis should include the granulomatous lesion such as tuberculosis, Crohn's disease, venereal lymphogranuloma, sarcoidosis, amebiasis, actinomycosis and pyogenic granuloma ${ }^{4} 516$.

The colonoscopic results vary from the colonic diffuse manifestation, with ulcerated granulomatous lesions in a continuous or non-continuous manner or areas of associated stenosis to plane ulceration with irregular borders, rigid and friable mucosa ${ }^{16}$. Our report adds the identification of plane ulcerated lesion with small dimensions which is associated with another circumferential lesion, non-stenosing, ulcerated and covered by fibrin. The colonoscopy results are possibly underestimated, since there is no systematic evaluation in the absence of a specific symptom. The differential diagnosis should include unspecific ulcerative rectocolitis, and in the segmentary form, Crohn's disease, intestinal tuberculosis and colorectal neoplasia ${ }^{126}$.

In recent years, knowledge of the natural history of South-American Blastomycosis and increased therapeutic arsenal has enabled a reduction in the diagnosis of the extension of the disease by means of autopsies $^{14}{ }^{15}$, coupled with an increase in diagnosis through image examinations. The gastrointestinal manifestations initially described through radiological exams $^{23710121315}$, have being replaced by endoscopic ${ }^{9}$, colonoscopic ${ }^{16}$ and tomographic examinations ${ }^{2}{ }^{12}$; however, due to the small number of patients presenting anorectal disease, the absence of systematic evaluation of systemic disease has limited an understanding of the dissemination of anorectal disease.

This case emphasizes the fact that the anal manifestation of the disease is secondary and not primary, and those patients with anal PM should be better evaluated.

\section{REFERENCES}

1. Azevedo NA, Fernandes AC, Silva AG, Moreira MAR, Leite ACA, Moreira H. Diagnóstico por colonoscopia da Blastomicose sulamericana. Revista Brasileira de Colo-proctologia 20: 103-106, 2000.

2. Chojniak R, Vieira RAC, Lopes A, Altenfender JC, Godoy CE. Intestinal paracoccidioidomycosis simulating colon cancer. Revista da Sociedade Brasileira de Medicina Tropical 33: 309-312, 2000.

3. Cunha MAR, Pereira AA, Gouveia OF, Pimentel JRL, Saad M, Teixiera D, Miyahira AR. Contribuição ao estudo radiológico da blastomicose sul-americana no aparelho digestivo. O Hospital 69: 195-200, 1966.

4. Diniz MN, Gayer C, Orra HA, Silva RHR. Patologias coloproctológicas pouco frequentes. Jornal Brasileiro de Medicina 66: 181-185, 1994.

5. Felício F, d'Acampora AJ, Bauer O, Brandão CE, Rocha WJP. Lesão anal causada pelo "Paracoccidioides Brasiliensis". Relato de caso. Arquivos Catarinenses de Medicina 20: 63-65, 1991.
6. Fernandez JAC, Rosales TC, Naupari MO, Ayala L, Caller A, Del Aguila P. Blastomicosis sul-americana. Diagnóstico mediante colonoscopia. Arquivos de Gastroenterologia 16: 24-29, 1979.

7. Fonseca LC, Migone C. Paracoccidioidomicose do intestino delgado. Aspectos anátomo-clínicos e radiológicos em 125 casos. Revista do Hospital das Clínicas da Faculdade de Medicina de São Paulo 31: 199-207, 1976.

8. Franco M, Montenegro MR, Mendes RP, Marques AS, Dillon NL, Mota NGS. Paracoccidioidomycosis: A recently proposed classification of its clinical forms. Revista da Sociedade Brasileira de Medicina Tropical 20: 129-132, 1987.

9. Gabellini GC, Martinez R, Ejima FH, Saldanha JC, Módena JLP, Veludo MAL, Figueiredo JFC. Paracoccidioidomicose do estômago. Relato de caso e considerações sobre a patogenia desta lesão. Arquivos de Gastroenterologia 29: 147-152, 1992. 
10. Magalhães A. Paracoccidioidomicose (blastomicose sulamericana). Aspectos radiológicos. Revista do Hospital das Clínicas da Faculdade de Medicina de São Paulo 35: 147-155, 1980.

11. Martinez R. Digestive Tract Lesions. In: Franco M, Lacaz CS, Moreno AR, Del Negro G (eds) Paracoccidioidomycosis. $1^{\text {st }}$ edition, CRC Press, Boca Raton, p.289-302, 1994.

12. Martinez R, Belluci AD, Fiorillo AM. A tomografia computadorizada na avaliação do comprometimento abdominal na paracoccidioidomicose. Revista da Sociedade Brasileira de Medicina Tropical 21: 47-50, 1988.

13. Martinez R. Meneghelli UG, Dantas RO, Fiorillo AM. O comprometimento gastrointestinal da blastomicose sul-americana (paracoccidioidomicose). Revista da Associação Médica Brasileira 25: 31-34, 1979.

14. Montenegro MR, Franco M. Pathology. In: Franco M, Lacaz CS, Moreno AR, Del Negro G (eds) Paracoccidioidomycosis. $1^{\text {st }}$ edition, CRC Press, Boca Raton, p.131-150, 1994.

15. Moraes CR, Fiorillo AM, Costa JC. Lesões radiológicas na blastomicose sul-americana. O Hospital 71: 145-156, 1967.

16. Ribeiro PC, Anderi Junior E, Speranzini MB. Lesões granulomatosas anorretais específicas. Relato de três casos. Revista Brasileira de Colo-proctologia 7: 58-62, 1987. 